Maurer School of Law: Indiana University

Digital Repository @ Maurer Law

2009

\title{
Protecting Private Property with Constitutional Judicial Review: A Social Welfare Approach
}

Daniel H. Cole

Indiana University Maurer School of Law, dancole@indiana.edu

Peter Z. Grossman

Butler University

Follow this and additional works at: https://www.repository.law.indiana.edu/facpub

Part of the Property Law and Real Estate Commons, and the Social Welfare Law Commons

\section{Recommended Citation}

Cole, Daniel H. and Grossman, Peter Z., "Protecting Private Property with Constitutional Judicial Review: A Social Welfare Approach" (2009). Articles by Maurer Faculty. 357.

https://www.repository.law.indiana.edu/facpub/357

This Article is brought to you for free and open access by the Faculty Scholarship at Digital Repository @ Maurer Law. It has been accepted for inclusion in Articles by Maurer Faculty by an authorized administrator of Digital Repository @ Maurer Law. For more information, please contact rvaughan@indiana.edu. 


\title{
Protecting Private Property with Constitutional Judicial Review: A Social Welfare Approach
}

\author{
PETER Z. GROSSMAN, DANIEL H. COLE* \\ Butler University; Indiana University School of Law - Indianapolis
}

This article uses a social welfare approach to determine if and when the institution of constitutional judicial review of property regulation and expropriation is efficient. A model is proposed in which property rights protection is a component of social costs. Constitutional judicial review is assumed to either add to or subtract on net from those costs, affecting social welfare generally. It will be shown that under realistic conditions, reflected in real instances, that constitutional judicial review might not enhance economic efficiency or overall social welfare. We show that the efficiency of constitutional judicial review is likely to vary within the larger institutional context.

\section{INTRODUCTION}

To what extent, if at all, does constitutional judicial review efficiently protect private property rights from government expropriation or over-regulation of private property rights? The conventional phrase "judicial review" is in this context modified by the adjective "constitutional" in order to avoid a potentially misleading ambiguity. "Judicial review" simpliciter describes not a single power of the courts but various powers that we seek to unpack by distinguishing between "constitutional judicial review" and "statutory judicial review." The former refers to the powers of courts to (a) overturn duly enacted legislation and/or (b) require some legislative action, such as payment of compensation, based on the courts' interpretation of higher legal authority, usually in the form of a written constitution. "Statutory judicial review," by contrast, describes far the less potent judicial authority to interpret, apply, and enforce legislation. In the US, courts

\footnotetext{
* The authors wish to thank Robert Main, a session of the Int'l Society for the New Institutional Economics (Boulder, CO, 2006), and an anonymous referee for helpful comments and suggestions.
} 
exercise both constitutional and statutory judicial review. In the UK, by contrast, courts exercise only statutory judicial review. ${ }^{1}$

This paper considers the social welfare implications of what we have defined as "constitutional judicial review." We presume that constitutional judicial review is instituted in order to enhance social welfare by limiting the authority of legislatures to enact laws that might otherwise reduce social welfare. ${ }^{2}$ One such constitutional limitation on legislative authority is found in the Fifth Amendment to the US Constitution, which prohibits the government specifically the federal government, but by extension of the Fourteenth Amendment, state and local governments as well - from "taking private property for public use, without just compensation." The question is: does a constitutional Takings Clause enhance social welfare, and if so, how much? In its absence, would legislative/political institutions run roughshod over private property rights, leading presumably to substantially lower levels of investment and, in the aggregate, economic growth?

This paper looks primarily at the efficiency characteristics of constitutional judicial review for protecting private property against expropriation or overregulation by governments, and examines the institution from a theoretical standpoint by modeling the welfare costs and benefits that judicial review entails. Like Komesar (2001), we are concerned with second-best alternatives; presumably, we want, as Coase suggested (1964:195), to choose the institutional arrangement that fails least. In some instances, it seems plausible that constitutional judicial review would be the most efficient or (what amounts to the same thing) the least inefficient solution to the problem of protecting private property rights. There may be other cases, however, especially in countries with long established formal and informal institutions of property rights protection, where the benefits from constitutional judicial review, as Fischel (1995) argues and the empirical record seems to confirm, are limited. In some circumstances, the social costs entailed by the process of constitutional judicial review may not be worth the social benefits. In those cases, the least inefficient solution could be to limit or even abandon the use of constitutional judicial review. ${ }^{3}$

\footnotetext{
${ }^{1}$ It might be argued that under the 1998 Human Rights Act, the UK courts can declare an enactment of Parliament unconstitutional or, at least, inconsistent with constitutional principles, but such a declaration cannot have the effect of negating the enactment. Only Parliament can negate, repeal, or amend an act of Parliament (Cole, 2007a:165-66).

${ }^{2}$ It is conceivable, however, that the power of constitutional judicial review might have a purpose other than, or in addition to, enhancement of social welfare. For example, it might be instituted to enhance the authority of some interest groups, (for example, judges) over others (such as legislators) regardless of social welfare effects.

3 As a practical matter, in the US this would require a constitutional amendment to repeal the Fifth Amendment's Taking Clause. Since repeal itself would entail substantial transaction costs, a
}

Review of Law \& Economics, ( 92009 by bepress 
The paper proceeds as follows: In the next section, we sketch a model of social welfare incorporating constitutional judicial review. In section three, we consider three hypothetical cases to examine under what conditions the benefits of constitutional judicial review of government regulations and expropriations of private property will be on net a social cost or benefit. In section four, we review empirical examples from the UK and the US that raise questions about the efficiency of constitutional judicial review in a system with well-established formal and informal norms of property rights. A concluding section discusses the context of constitutional judicial review and suggests avenues for future research.

As a caveat, we should add that this paper makes no arguments and draws no conclusions about the propriety or desirability of constitutional judicial review for purposes other than protecting private property against government expropriation or over-regulation. We do not suppose, for example, that the socially optimal level of constitutional judicial review for protecting private property rights would necessarily be the same as the optimal level for protecting rights of free speech, religious liberty, voting, or due process. There is no ex ante warrant to believe that all rights would be equally well protected by political or judicial institutions. To the contrary, there is reason to suppose that differential levels of constitutional judicial review might be desirable, depending on the structure of incentives, which may differ across various legal or constitutional rights. For instance, judicial review is likely to be particularly valuable for protecting "discreet and insular minorities," whose rights are unlikely to be protected by majoritarian political interests (United States v. Carolene Products Co., 304 US 144, 153 n.4 (1938); Ely, 1980). This was, in fact, James Madison's concern about private property owners (Ely, 1998:54). Our reading of English legal history and the positive political economy literature suggests that Madison may have been wrong to believe that property owners constitute a vulnerable minority. Even if we are right about that, however, constitutional judicial review might still be warranted to protect other constitutional rights belonging to minority groups that are truly vulnerable to majoritarian oppression. This paper, however, is concerned only with the social welfare implications of constitutional judicial review for protecting private property rights against government expropriation or over-regulation.

further analysis would be needed to determine that the cost of continuing to live with, and abide by, the Fifth Amendment's Taking Clause exceeded the cost of repealing that clause.

http://www.bepress.com/rle/vol5/iss1/art10

DOI: $10.2202 / 1555-5879.1309$ 


\section{ANALYTIC FRAMEWORK: A SOCIAL WELFARE MODEL}

The economic literature has for many years grappled with the problem of modeling social welfare. When it is represented in functional form, it usually takes on a character such as $W=\sum a_{i} W_{i}\left(U_{i}\right)$ where social welfare $(W)$ is a weighted sum of each individual's utility ordering. As Arrow (1950) pointed out long ago, a social welfare function faces an insuperable aggregation problem in that interpersonal utility, which is in each case an ordinal ranking, cannot be sensibly aggregated (Craven, 1992). Still, such functions (or "functionals" as they are sometimes called) are often used to at least explicate the direction of social welfare maximization.

For our purposes, we have chosen a simpler functional argument. In "The Problem of Social Cost," Coase (1960) chose to address the welfare goal as a vaguely expressed maximization of "the social product" generally thought to be the total, or the optimal, output. We follow this basic approach with a "Coasian" social product function as a proxy for social welfare. This does not truly circumvent the problems inherent in social welfare models since output will depend partly on demand functions that stem from implicit interpersonal utility calculations, and thus the aggregation problem remains. But this form allows for a clear means of weighing some potential efficiency aspects of constitutional judicial review as they affect the costs of transactions.

We assume, therefore, a social welfare function in which the goal is wealth creation and the goal of society is to maximize the social product $(\Pi)$. This function is a summation across producers within society and represents efficient production. The functional form is:

$$
\Pi=\sum \mathrm{PY}(\mathbf{x})-[\mathrm{C}(\mathbf{x})+\mathrm{T}(\mathbf{x}, \alpha(\mathrm{J}), \mathrm{J})]
$$

In this equation, the social product depends on the value of output: a price level $(P)$ and total output $(Y)$ which is a function of a vector of inputs, $x$. Effectively $Y(x)$ represents a general production function in which $(x)$ includes inputs broadly defined to take in all resources that are required of the transformation process. All producers are assumed to seek to maximize profits, and the sum of the output levels of all producers multiplied by prices equals the value of social product. The level of social product, of course, depends on costs, and output will be assumed to expand until marginal benefits are equal to marginal costs.

Thus, the cost component $C(x)+T(x, \alpha(J), J)$ is the crucial element that determines the level of social product. ${ }^{4}$ This component consists of two

\footnotetext{
${ }^{4}$ It is not assumed that there is a specification of optimal (or best possible) property rights that is, or can be, attained. This cost function examines instead an aspect of the cost of enforcement of property rights through judicial review.
}

Review of Law \& Economics, (C) 2009 by bepress 
elements, $C$ and $T$. The former represents transformational costs, the costs of factors of production that go into generating social product. It is a function of a vector of inputs $(x)$ and will be rising as production increases. The second cost term $T$ represents transaction costs. In the world of the so-called "Coase Theorem," $T$ would be set equal to zero. But given the reality of exchange relations, contracts, monitoring, measurement, property rights and so on, $T$ will always be positive. Indeed, without these transactional aspects of exchange, production does not occur and no benefits can be realized.

Consequently, transaction costs are also a function of a vector of inputs that go into generating the social product. And like the transformational variable, $T$ is positively related to $x$.

But transaction costs are also a function of the institutional matrix (North, 1997). Most importantly, transaction costs are affected by the structure of property rights, which facilitates or impedes exchange. The property rights structure is substantially a function of legal definition and enforcement by executive-branch agencies, and/or legislative bodies. The rules that define and secure private property rights are designated here by what we are terming the institutional variable $\alpha$. In general, it is assumed that $\alpha$ is positively related to $T$ (North, 1997). That is, the process of defining and enforcing property rights though the judicial, executive and/or legislature branches of government entails costs. The more effort that is expended in defining and enforcing such rights, the more costs are imposed. However, the costs will vary according to the nature of the legal system and other features of the institutional environment. We assume that every country has an institutional structure designated by $\alpha$, but for the purposes of this model the institutional structure need not be the same in each society, and the costs different institutional structures impose on transactions may vary. In other words, transaction costs related to property rights in country $i$ are not necessarily identical to those in country $j$. We assume that when it is difficult to delineate property relations or to enforce property rights, transaction costs will be high. A very high value for $T(\alpha)$ (a highly uncertain environment for exchange) means total costs will be high and the social product low. A low value of $T(\alpha)$ conversely would mean that transaction costs related to property rights are low and so the cost of exchange is low. Very well defined property rights would in fact reduce the cost of production and exchange, while poorly defined rights would mean that transaction costs are high, adding substantial costs to exchange, and therefore reducing the social product. (In theory $T(\alpha)$ could be so high that no exchange would be possible.)

While we assume for simplicity that transaction costs rise with efforts to increase the security of private property rights, it is clear that some changes in the rules and their enforcement will actually lower costs. For purposes of this analysis, we are 
assuming only that one institutional factor will change the cost of securing private property, and that factor is constitutional judicial review. ${ }^{5}$ Thus, it is assumed that $\alpha$ is a function of constitutional judicial review $(\alpha=f(J))$, and the standard expectation is that they are negatively related. That is, as J rises, there is more clarity in the definition and security of property rights, and so the cost of exchange falls (except if the judiciary are corrupt, self-interested or incompetent, as we discuss in the next section). It is assumed that $T(\alpha)>0$ in all cases. If $T(\alpha)$ were in fact equal to zero, all costs related to property rights would be zero and judicial review would be irrelevant. Where no judicial review exists, of course, $\alpha(J)=0$.

It is further assumed in (1) that transaction costs $(T)$ are themselves affected by constitutional judicial review $(J)$. The process itself (litigation, enforcement, etc.) creates social costs, and the uncertainty created by potential litigation and redistribution of rights imposes positive costs on market participants. Indeed, it can be said that if judicial review were costless, it would always be beneficial (that is it would always lower $T(\alpha)$ ). But of course it is not costless. As courts introduce more judicial review, transaction costs through $T(J)$ rise (although $T(\alpha)$, and transaction costs overall, may either fall or rise as a consequence).

In this model, the standard maximization assumption applies. That is, the marginal benefit - here the value of the marginal product of output-must equal the marginal cost of those resources. Since a price level is a given, the marginal benefit will be determined by the marginal product. We assume diminishing returns and therefore the marginal product increases at a diminishing rate, and so social product is increased the lower the level at which the value of the marginal product equals marginal costs.

Marginal costs can be expressed as a sum:

$$
\frac{d C}{d x}+\frac{d T}{d x}+\frac{d T}{d \alpha}+\frac{d T}{d J}=\mathrm{MC}
$$

The key innovation in this structure is the potential role of constitutional judicial review. To understand the role of constitutional judicial review, $T$ must be differentiated with respect to $J$ and $\alpha$, which in turn is differentiated with respect to $J$. This yields:

\footnotetext{
5 Clearly this is a simplification. Other institutional factors can lower the cost of securing property rights. Indeed, one could easily have a function for $\alpha$ containing several arguments that would bear on the cost of exchange. There could also be an endogeniety issue in that a low $T(\alpha)$ country could have reached that point because it has judicial review. For the purposes of this analysis, however, the institutional background is taken as given and only constitutional judicial review will change its impact on transaction costs.
}

Review of Law \& Economics, (C) 2009 by bepress 
Judicial Review: A Social Welfare Approach / 239

$$
\frac{d T}{d \alpha}+\frac{d T}{d J}=\frac{\partial T}{\partial \alpha} \bullet \frac{\partial \alpha}{\partial J}+\frac{\partial T}{\partial J}
$$

$(+)(-)(+)$

This equation suggests, as we argue below, that constitutional judicial review of government regulation and expropriation of private property has ambiguous effects on social cost and hence on social product. First, as property rights are delineated and protected, transaction costs $\frac{\partial T}{\partial \alpha}$ rise. We can assume, therefore, that the effect of changing or securing property rights is to raise the marginal social cost of transactions. However, it is further assumed that, in general, constitutional judicial review lowers costs because it clarifies and protects private property rights. In that case, $\frac{\partial \alpha}{\partial J}$ would be negative, implying that the first term on the right side of the equation is negative. In other words, constitutional judicial review should lower the marginal costs of transactions overall.

But the second term, $\frac{\partial T}{\partial J}$, certainly is positive. Constitutional judicial review imposes transaction costs of its own. As noted, there are litigation and enforcement costs. Moreover, there is some uncertainty as to whether or not judicial review will resolve issues connected to the security of rights. As the process of judicial review unfolds, property rights remain uncertain or mutable with respect to government action until a rule has been litigated, and possibly even after litigation if the courts failed to adequately define or protect them. Producers and property holders generally need to expend resources on, among other things, legal services and information. Lingering uncertainty may raise costs over time as the prospect, indeed just the possibility, of additional litigation requires added expenditures of resources on legal, financial, and other services.

But what about the sum of the terms? The standard assumption among legal scholars is that the reduction in costs through the sure enforcement of property rights because of constitutional judicial review will lower transaction costs generally. That is, judicial review will reduce $T(\alpha)$ and this is assumed to exceed the cost of the process. But since courts, through constitutional judicial review, have the power to overturn laws that redistribute property rights (or to raise the cost of transactions by requiring compensation) producers generally will have to take into account the implicit and explicit costs of the review process. On that basis, constitutional judicial review could cost more than it creates in benefits, lowering the social product. In that event, so far from being necessary to property rights protection and economic efficiency, it would be a burden.

http://www.bepress.com/rle/vol5/iss $1 /$ art10

DOI: $10.2202 / 1555-5879.1309$ 
Put more simply, constitutional judicial review is efficiency enhancing overall only when the following condition is met:

$$
-\left(\frac{\partial T}{\partial \alpha} \bullet \frac{\partial \alpha}{\partial J}\right)>\frac{\partial T}{\partial J}
$$

In other words, constitutional judicial review only raises the social product when the value of the reduction in marginal costs from the further definition and protection of private property rights exceeds the marginal cost of providing constitutional judicial review.

\section{HYPOTHETICAL APPLICATIONS}

The question then is: when in fact does constitutional judicial review lower social costs and when does it raise them? We consider three general possibilities: the standard case, the "corrupt" judiciary case, and the welldefined property rights economy.

\subsection{THE STANDARD CASE}

The assumption among US legal scholars and jurists is essentially that judicial review inevitably lowers $T(\alpha)$ by a far greater percentage than it raises costs. The literature suggests that property rights would be trampled even though the US has a representative government made up of many property holders (Ely, 1998; Epstein, 1985). Those who claim that judicial review is a necessary condition for the maintenance of effective property rights are arguing in the terms laid out above that, in the absence of constitutional judicial review, the value of $T(\alpha)$ would be very high, leading to correspondingly high costs of production and exchange.

Yet, the ability of constitutional judicial review to lower costs to a great degree depends on the existence of an independent judiciary and reliable enforcement mechanisms. This leads to a curious outcome: Judicial review should have its greatest net benefit where there is a potentially predatory government and ill-defined property rights, but this predatory government has to be one that does not interfere either with an independent judiciary or the enforcement arms of the law. It would work best, therefore, in an environment where predators are restrained to a considerable degree whether there is constitutional judicial review or not.

Review of Law \& Economics, ( 2009 by bepress 
Judicial Review: A Social Welfare Approach / 241

\section{2. "CORRUPT" JUDICIARY}

The assumption of the standard case is that the judiciary acts in the public interest and that judges use judicial review to clearly define and strengthen property rights institutions. But there is no reason to believe that the judiciary always acts in the best interest of society. Indeed, Public Choice theory makes a convincing case that judges as well as legislators typically act in their own interest (Mueller, 1989). Where the judiciary is known to be corrupt or corruptible, the outcome of constitutional judicial review is unlikely to lower the costs of exchange. The same outcome may be true when the judiciary is not corrupt but simply self-interested, incompetent or merely inadequate to the task of processing the information needed to determine the optimal level of protection for private property rights.

Equation 4 presumes that the term $\frac{\partial \alpha}{\partial J}$ is negative: judicial review facilitates exchange and so lowers transaction costs. But a corrupt judiciary could use constitutional judicial review to make exchange more costly and lead to a $\frac{\partial \alpha}{\partial J}>0$.

In this instance, constitutional judicial review adds doubly to transaction costs: Both through the cost of the process and now also from the result. This would of course raise transaction costs and lower the social product.

A corrupt judiciary is, of course, not just a hypothetical problem. There is no inherent reason to assume, even in rule-of-law states, that the judiciary will never act pursuant to some agenda that in fact lowers social welfare.

\subsection{WeLL-DEFINED PROPERTY RIGHTS}

Consider a country with a long tradition of rule of law, property rights protection, social norms that validate property ownership, contract enforcement, clear property titles and other features of an economic and social system that is receptive to economic exchange. In this context, the efficiency of judicial review is most ambiguous.

Suppose, for example, that constitutional judicial review always will redefine or enforce property rights in such a way as to make exchange more certain. But in this instance, exchange already is highly certain. The amount by which the value of $\alpha$ changes with respect to $J$ cannot be large since the magnitude of $T(\alpha)$ is already small. True, the risk of predatory behavior by the legislature remains, but if this does not conform with informal institutions or within formal legal traditions, it seems the potential for predation is low and unlikely to be reduced to zero even if constitutional judicial review is introduced. In other words, the gain from judicial review, even if we assume it to be positive,

http://www.bepress.com/rle/vol5/iss $1 /$ art10

DOI: $10.2202 / 1555-5879.1309$ 
may fall short of the costs. The condition expressed in equation (4) will not be met since the right hand term will be larger than the one on the left.

Indeed, as we discuss in the next section there are cases in which there is no constitutional judicial review of legislation but where political institutions have long respected and protected private property rights.

\section{EMPIRICAL EXAMPLES AND THEORIES OF POSITIVE POLITICAL ECONOMY}

Cole (2007a) has shown that political institutions have protected property rights quite well in the United Kingdom, even though that country's courts lack the power of constitutional judicial review. That is to say, the UK's courts cannot overturn acts of Parliament or force Parliament to pay compensation when it expropriates or regulates private property rights. This finding surprises many jurists (particularly in America), who tend to presume, often quite casually, that in the absence of vigilant judicial protection under the Fifth Amendment's Takings Clause property rights in the US would quickly be ground into dust by rampant legislators and regulators. In other words, American legal scholars presume that constitutional judicial review is a strictly necessary institution without which private property rights would not long survive. And without well-protected private property rights, both liberty and economic productivity would be lost. This view has been articulated by jurists as diverse as James Madison (Ely, 1998:54), Oliver Wendell Holmes (Pennsylvania Coal Co. v. Mahon, 260 US 393, $415-6$ (1922)), and Antonin Scalia (Lucas v. South Carolina Coastal Council, 505 US 1003, 1025 n.12 (1992)).

In contrast to the presumed expectations of American jurists, private property rights have not disappeared in the UK. Indeed, Parliament only rarely expropriates anyone's private property by eminent domain; and when it does take title, Parliament virtually always pays compensation, even though no court in the land can force it to do so (Cole, 2007a). Generally speaking, Parliament acts as if its power to expropriate were limited by constitutional judicial review. Like legislatures in the United States, which are constrained by the Fifth Amendment's Taking Clause, Parliament usually regulates the use of private property without paying compensation. But when Parliament's regulations deprive privately owned lands of virtually all economic value or it simply takes away title, Parliament invariably compensates. For example, in the Town and County Planning Act of 1947, as amended in 1990, Parliament provided for landowners to be compensated if the denial of planning permission left their land without any "reasonable beneficial use" (Cole, 2007a). This provision has much the same effect as the US Supreme Court's ruling in Lucas v. South Carolina Coastal Council, 505 US 1003 (1992). The UK's Town and County Planning Act also

Review of Law \& Economics, ( 2009 by bepress 
allows for consideration of landowners' reasonable and legitimate "development expectations," which is analogous to the "reasonable, investment-backed expectations" test the US Supreme Court enunciated in Penn Central Transportation Co. v. City of New York, 438 US 104 (1978). Apparently, the UK has managed to achieve a roughly similar outcome, but without incurring the costs associated with instituting and exercising constitutional judicial review.

The reasons for Parliament's self-restraint are, no doubt, rooted in the customs and conventions - the informal institutions - of English legal history, which may (or may not) differ markedly from those of US legal history. But Parliament's selfrestraint is also explained to some extent by recent theories of positive political economy, which should apply equally to legislative bodies in the US.

Whatever the reasons for its remarkable-and to many American jurists, incomprehensible-self-restraint, the fact remains that Parliament very substantially protects private property rights in the UK even without the constraints of constitutional judicial review. According to the Heritage Foundation's annual Index of Economic Freedom, the UK regularly receives the highest ranking for protecting property rights (1.0), the same score the US receives. According to another ranking (Gwartney and Lawson, 2004), the UK ranks fifth in the world, 11 positions ahead of the US, for "Legal Structure and Security of Property Rights." Whatever the merits of such rankings, it seems clear that the UK has a positive reputation for protecting private property rights, despite lacking constitutional judicial review. Consequently, according to the model set out in the last section, if constitutional judicial review were instituted in the UK any positive impact on $\alpha$ would likely be relative small, smaller perhaps than the cost $\frac{\partial T}{\partial J}$. In other words, constitutional judicial review in the UK could fail the condition specified for efficiency in equation (4).

The long history of political protection of private property rights in the United Kingdom cuts strongly against the notion that constitutional judicial review is in fact strictly necessary to protect the institution of private property. Moreover, recent theories of positive political economy provide reasons for believing that democratic political/legislative institutions, especially at higher levels of government, can be expected to protect the rights of private property owners, who are far from constituting a "vulnerable minority" (Cole, 2007a). For example, Sened (1997) finds that completely self-interested, rent-seeking governments can be expected to establish and enforce private property rights in order to secure political and military support, as well as revenues, necessary for their survival. Glaeser et al. (2004) and Knack and Keefer (1995) both demonstrate that secure property rights are an important component of the state's institutional structure because they provide a necessary basis for capitalization and economic exchange, 
which result in economic growth and provide revenues, via taxation, to the government. Empirical information confirms that governments which do not provide secure property rights do not survive as long. According to Clague et al. (1996), property and contract rights are significantly associated with a proxy for the time horizons for autocrats (the log of years in power) and, in democracies, with the duration of democratic government. This does not necessarily mean that property institutions will be structured to maximize social welfare. North (1981:22) rightly notes that "[p]roperty rights that produce sustained economic growth have seldom held sway throughout history..." However, it is clear that governments have at least some substantial incentive to provide and secure private property rights. To the extent they do not do so, Sened (1997:101) suggests the basic problem may be incomplete information.

Taken together, modern theories of positive political economy and the historical evidence from the UK suggest that the institution of constitutional judicial review may provide rather less marginal social benefit than many jurists commonly suppose.

Other scholars, both from economic and legal perspectives, have started to question the efficiency of constitutional judicial review. Economist William Fischel (1995), for example, has argued that private property owners often are able to protect their own interests through their use of political processes, without recourse to the courts. Legal scholar Neil Komesar (2001), meanwhile, has questioned not the theoretical value of judicial review (which he endorses) but rather the practical ability of the courts to meet the need and effectively limit government incursions on private property rights. Komesar makes an efficiency argument that judicial institutions may fail so badly that a secondbest alternative of a "corrupt, excessive, and repressive [legislative] regulatory process" may actually cause property owners less harm (2001:106).

Though critics of constitutional judicial review for protecting private property rights have made plausible arguments against its efficiency, none have subjected the concept of judicial review to a general welfare analysis. Theoretically, there may be cost-reducing effects from judicial review, but the process is itself costly. Thus, the question arises as to whether the social benefits of constitutional judicial review always (or ever) outweigh its costs. Note that the costs entail not only the transaction costs of the legal system but also the prospect that judicial rulings will overturn legislative action and lead to greater uncertainty about property rights and enforcement. Simply put, it has not yet been established in the literature under what conditions the benefits of judicial review actually make it the least (or a less) costly alternative.

It is worth noting that the UK is not the only example of a country that relies predominantly on political institutions to protect private property rights. The

Review of Law \& Economics, ( 2009 by bepress 
same is true for many other commonwealth countries (Allen, 2000). Even in the US, where property rights are constitutionally protected, it would be inaccurate to assume that property rights are enforced only by the courts. Legislative bodies also protect property rights. Consider, for example, the aftermath of the US Supreme Court's widely unpopular decision in Kelo v. City of New London, 545 U.S. 469, 125 S.Ct. 2655 (2005). In Kelo the Court ruled (not for the first time) that eminent domain takings for the purpose of economic development could satisfy the Public Use Clause of the Fifth Amendment. The majority's decision was based on several precedents extending back for more than 100 years (Cole, 2006). However, Justice O'Connor, in dissent, argued vehemently that the Court in Kelo had undermined all private property rights in the United States by leaving it "vulnerable to being taken and transferred to another private owner, so long as it might be upgraded" (Kelo, 125 S.Ct. at 2671, O'Connor, J. dissenting).

The Court's ruling in Kelo led to a surprising (to legal scholars at least) public backlash, as property-rights advocates, the news media, and state and federal legislators on both sides of the aisle lashed out against the Court's failure to uphold the institution private property (Cole, 2006, 2007b). As a direct consequence, virtually every state legislature in the United States considered, and more than three dozen actually enacted, new laws at least purporting to constrain the power of eminent domain. As of this writing, more than 400 separate legislative proposals to limit eminent domain are still awaiting action in state legislative bodies (Cole, 2007b:10543). ${ }^{6}$ The vast majority of these measures will never be enacted into law, but some will be enacted, and of those at least a few are likely to impose substantial limits on the power of eminent domain. Indeed, some of the measures already enacted in the wake of Kelo impose constraints that are significantly more protective of private property rights than any the dissenters in Kelo (with the exception of Justice Thomas') would have imposed.

To cite one example: The State of Indiana's new eminent domain law, H.B. 1010, enacted in March 2006, responds directly to Kelo by imposing a restrictive definition of "public use," which excludes "economic development, including an increase in a tax base, tax revenues, employment, or general economic health." Indiana further limits the use of eminent domain to "public nuisances," "fire hazards," "structures unfit for human habitation," and "unimproved or vacant" lands. Sites that do not fall into one or another of these categories cannot be condemned. And for sites that still can be taken, H.R. 1010: requires takers to make "good faith" efforts to purchase the

\footnotetext{
${ }^{6}$ For example, http://maps.castlecoalition.org/legislation.html.

7 Justice Thomas would interpret the phrase "public use" literally to allow eminent domain takings only in cases where the land would be devoted to use by the public, such as public roads and public parks.
}

http://www.bepress.com/rle/vol5/iss1/art10

DOI: $10.2202 / 1555-5879.1309$ 
property before resorting to eminent domain; allows landowners who fight against eminent domain to seek reasonable attorneys fees; and provides for super-compensation (i.e., above market value). In the case of agricultural lands, the government must pay $125 \%$ of fair market value; and for occupied residential properties, the government must pay $150 \%$ of fair market value. In sum, Indiana's new eminent domain statute very substantially restricts the use of eminent domain in that state. It constitutes legislative protection of property rights against legislative or administrative incursion; it provides evidence in support of the positive political economic theories of property discussed earlier; and it all but rules out the need for constitutional judicial review to protect private property rights in the State of Indiana.

Indiana's new eminent domain statute may not be representative. Statutes enacted in other states may be more or less protective of private property rights. But the fact remains that, in the wake of Kelo, political bodies are responding to the perceived demand for more protection of private property. To the extent state legislatures are responsive and protect private property rights, the social value of constitutional judicial review for accomplishing the same purpose is arguably reduced. As suggested by the model elaborated in Section 2, constitutional judicial review can provide incrementally greater protection for private property rights on top of the protection already provided by the political system (although that does not seem, in fact, to be the case with respect to limitations on eminent domain in the US), but only at some positive cost. The question, as always, concerns the marginal costs and benefits of providing further increments of protection for property rights through the institution of constitutional judicial review.

Some might argue that the Court's ruling in Kelo maximized social welfare according to the basic "social product" model we have delineated in Section 2. That is, the first term on the right of equation (1) might have been larger with the court's ruling that without it. But this seems unlikely for several reasons. First, had there been no constitutional judicial review, the outcome of the dispute would have been the same - condemnation of the plaintiffs' properties - but without attendant court costs. ${ }^{8}$ Second, if the plaintiffs subjectively valued their homes more highly than the Court's assessment of "just compensation," they could have suffered what Michelman (1967) refers to as "demoralization" costs - losses of

\footnotetext{
${ }^{8}$ It could, perhaps, be argued that the Kelo decision contributed to social welfare by spurring legislatures to enact welfare-enhancing laws protecting property rights, but such an attenuated effect would be difficult to credit because: (a) there is no evidence that the Court decided Kelo with the aim of spurring legislation (although Justice Stevens noted that states could provide greater protections for private property, if they wished to do so); and (b) the political outrage that drove the legislation might have been just as great, or greater, in the absence of constitutional judicial review.
}

Review of Law \& Economics, ( 2009 by bepress 
utility greater than the benefits from enhanced production. ${ }^{9}$ Demoralization costs could also have affected other property owners including, for example, small producers and start-up companies, that might have been deterred from making productive investments out of fear that the government would later forcibly transfer their properties to larger corporations.

Even if constitutional judicial review in Kelo had unambiguously enhanced social welfare, it would not have answered the following counterfactual: In a country like the US, would the social costs have been higher and/or the benefits lower had constitutional judicial review been unavailable? All that is really clear from the Kelo case is that state legislatures in the U.S. are sensitive to political pressures to maintain strong property rights; they would likely do so to a significant extent even in the absence of constitutional judicial review. And avoiding judicial review would clearly have saved the costs $\left(\frac{\partial T}{\partial J}\right)$ of applying it.

Moreover, while the model in Section 2 looks at marginal changes, ultimately the question is: does the sum of the marginal changes from constitutional judicial review across the run of cases reduce or increase net social welfare?

\section{DISCUSSION AND CONCLUSION}

There is undoubtedly a substantial amount of anecdotal evidence on the costs and benefits of constitutional judicial review in different countries. Over 50 countries in the world have Constitutional Courts tasked with overturning laws that violate constitutional provisions. Comparisons can be made between countries with and without constitutional judicial review at similar levels of development, as well as between countries with review procedures but different perceived levels of economic freedom.

Indeed, many countries despite judicial review are notable for high levels of corruption and weak enforcement of property rights. Russia, for example, has a constitutional court but is also considered extremely corrupt (147 out of 180 on the transparency index) with poor protection of property rights. Poland, a country that has undergone a similar transition to a market economy and is at a comparable level of development to Russia, also has a constitutional court. But Poland is rated 58th with respect to corruption and is considered to have a greater respect for property rights. ${ }^{10}$ It would be instructive to analyze the consequences of constitutional rulings with respect to property rights in both

\footnotetext{
${ }^{9}$ Strictly, Michelman focused on cases of non-compensation rather than under-compensation. But his basic arguments about demoralization costs apply in both contexts.

${ }^{10}$ Respect for property rights is taken from the Heritage Foundation's 2004 Index of Economic Freedom; the corruption ranking is from the Transparency International 2008 Corruption Perceptions Index.
}

http://www.bepress.com/rle/vol5/iss1/art10

DOI: $10.2202 / 1555-5879.1309$ 
of these countries. How have judicial decisions by the constitutional courts impacted the rights of property holders and markets for property in those countries? Of course, as we have suggested, a comparison of the larger institutional structure would be needed to assess the magnitude of $T(\alpha)$.

The model we have proposed may also provide a basis for quantitative tests of constitutional judicial review. Cost comparisons could include the difficulty/costliness of utilizing the courts and the costs of court enforcement. Further, comparisons might also look at property markets in these countries to assess whether rulings have made an impact on the cost of title transfers and the perceived security of title itself. In general, asset valuations, legal costs, title insurance rates across countries, might provide more or less accurate ways of estimating the effects on transaction costs from constitutional judicial review, and provide estimates of values for the variables in this paper's model.

Experiments might also be structured to test the market effects of constitutional judicial review. For example, "judges" might be presented with cases involving property rights under varying conditions, in which their decisions might make title more or less secure against government expropriation, make land assembly for (re)development more or less costly, or otherwise impact overall social welfare. It might then be examined what the court will rule if (a) there is a tradition of property protection that is thought to be in everyone's interest; (b) bribery is tolerated but (a) generally applies; (c) bribery is typical but arguments to a "judges" self-interest may be made that include taking the lesser bribe; (d) courts cannot rule but a "legislature" makes the rules under similar kinds of incentives as those above. Obviously, various kinds of institutions may be added to the proceedings to observe how and why the behavior of participants changes.

The model might also be expanded beyond constitutional judicial review to include other variables that would affect the value of $T(\alpha)$. Here the variable $J$ is a limited subset of the legal factors that might raise or lower the costs of exchange. For example, in the US and elsewhere, courts rule on property cases concerning nuisance and trespass that can have important effects on the definition and enforcement of property rights. Similarly, courts routinely decide cases that either strengthen or reduce the cost of contracting and hence the costs of deferred exchange. This paper, however, focuses exclusively on the issue of constitutional judicial review and its effects on property rights for two reasons: First, because constitutional judicial review plays an obviously prominent role in establishing and securing property rights in the US; second, because many legal scholars claim that constitutional judicial review is a necessary institution for protecting property rights to maximize the social product.

Our model and evidence provide reasons to question whether constitutional judicial review is as important as those scholars have asserted, and most

Review of Law \& Economics, ( 2009 by bepress 
Judicial Review: A Social Welfare Approach / 249

American jurists casually assume. It would seem that the underlying institutions, and the place of property rights among those institutions, are at least as important. Constitutional judicial review without a basic social and legal prominence for property rights protection may not guarantee that such review will secure rights, and may not be efficiency enhancing. Basic respect for property rights within the legal and social tradition may also make constitutional judicial review a (comparatively) inefficient institution. Arguably, it might obviate the need for constitutional judicial review at all.

\section{REFERENCES}

Allen, Tom. 2000. The Right to Property in Commonwealth Constitutions. Cambridge: Cambridge University Press.

Arrow, Kenneth J. 1950. "A Difficulty in the Concept of Social Welfare," 58 Journal of Political Economy 328-346.

Clague, Christopher, Philip Keefer, Stephen Knack, and Mancur Olson. 1996. "Property and Contract Rights in Autocracies and Democracies," 1 Journal of Economic Growth 243-276.

Coase, Ronald H. 1960. "The Problem of Social Cost," 3 Journal of Law and Economics 1-44. . 1964. "Discussion: The Regulated Industries," 54 American Economic Review 194-197.

Cole, Daniel H. 2006. "Why Kelo Is Not Good News for Local Planners and Developers," 22 Georgia State University Law Review 803-855. . 2007a. "Political Institutions, Judicial Review, and Private Property: A Comparative Institutional Analysis," 15 Supreme Court Economic Review 141-181. 2007b. "Kelo's Legacy," 37 ELR News \& Analysis, 10540-10546.

Craven, John. 1992. Social Choice: A Framework for Collective Decisions and Individual Judgements. Cambridge: Cambridge University Press.

Ely, James W., Jr. 1998. The Guardian of Every Other Right: A Constitutional History of Property Rights. Oxford: Oxford University Press.

Ely, John H. 1980. Democracy and Distrust: A Theory of Judicial Review. Cambridge, MA: Harvard University Press.

Epstein, Richard A. 1985. Takings: Private Property and the Power of Eminent Domain. Cambridge, MA: Harvard University Press.

Fischel, William A. 1995. Regulatory Takings: Law, Economics, and Politics. Cambridge, MA: Harvard University Press.

Glaeser, Edward L., Rafael LaPorta, Florencio Lopez-de-Silanes, and Andrei Schleifer. 2004. "Do Institutions Cause Growth," 9 Journal of Economic Growth 271-303.

Gwartney, James, and Robert Lawson. 2004. Economic Freedom in the World: 2004 Annual Report. Washington, DC: Cato.

Heritage Foundation. 2004. Index of Economic Freedom, http://www.heritage.org/ research/features/index/index.html.

http://www.bepress.com/rle/vol5/iss $1 /$ art10

DOI: $10.2202 / 1555-5879.1309$ 
Knack, Stephen, and Philip Keefer. 1995. "Institutions and Economic Performance: CrossCountry Tests Using Alternative Institutional Measures," 7 Economic \& Politics 207-27.

Komesar, Neil K. 2001. Law's Limits: The Rule of Law and the Supply and Demand of Rights. Cambridge: Cambridge University Press.

Michelman, Frank I. 1967. "Property Utility, and Fairness: Comments on the Ethical Foundations of 'Just Compensation'," 80 Harvard Law Review 1165-1258.

Mueller, Dennis C. 1989. Public Choice II. Cambridge: Cambridge University Press.

North, Douglass C. 1981. Structure and Change in Economic History. New York: WW Norton. . 1997. "Transaction Costs Through Time," in Claude Menard, ed. Transaction Cost Economics. Cheltenham: Edward Elgar.

Sened, Itai. 1997. The Political Institution of Private Property. Cambridge University Press.

Transparency International. 2008. Transparency Perceptions Index, http://www.transparency.org/ news_room/in_focus/2008/cpi2008/cpi_2008_table.

Review of Law \& Economics, (C) 2009 by bepress 